\title{
Pharmaceutical treatment of primary open angle glaucoma
}

\author{
Mashael Al-Namaeh ${ }^{1,2}$ \\ ${ }^{1}$ Eye Research Center, Wayne, PA, USA \\ ${ }^{2}$ Oulu University of Applied Sciences, Oulu University, Finland
}

\begin{abstract}
Background: Glaucoma is a progressive, irreversible optic neuropathy that results in serious vision loss and blindness. This review aimed to summarize key concepts of primary open angle glaucoma (POAG) pharmaceutical treatment trials over the last decade.

Methods: We searched PubMed/MEDLINE and clinicaltrials.gov from January 1, 2010, to August 31, 2020, using the key words "POAG" and "Ocular topical therapeutics". This search yielded 77 and 120 papers, respectively.

Results: Thirty-three records were compatible with our inclusion criteria. Pharmaceutical treatment is a common intervention in POAG for lowering IOP. Prostaglandin (PG) analogues are most commonly recommended as initial medical therapy, which are administrated either as a monotherapy or in combination with other IOP-lowering classes of medications. Alternative therapies, such as $\beta$-blockers, $\alpha-2$ adrenergic receptor agonists, and topical carbonic anhydrase inhibitors, have been used in combination or as a monotherapy. Rho-kinase inhibitors, such as netarsudil $0.02 \%$, AR-13324 0.02\%, and ripasudil are new IOPlowering medications. Despite IOP reduction, there is a significant number of patients with POAG that may experience disease progression, and the risk of blindness over the long term is considerable.

Conclusions: Clinical trials have indicated that pharmaceutical treatment of POAG is effective and safe. In addition, the new novel Rho-kinase inhibitors have shown significant IOP reduction. The new fixed combinations have also yielded significant reductions in IOP. POAG is a cause of irreversible vision loss, if not diagnosed and treated early. The condition is likely to progress in a significant number of patients, with a considerable risk of blindness in the long-term.

\section{KEY WORDS}

primary open angle glaucoma, POAG, intervention study, randomized clinical trials, RCTs, drug therapies, pharmaceutical treatment, medical therapy, prostaglandin analogues, beta adrenergic blockers, $\alpha-2$ adrenergic receptor agonist, carbonic anhydrase inhibitor, Rho-kinase inhibitor
\end{abstract}

\section{INTRODUCTION}

Glaucoma is the second leading cause of blindness worldwide. Primary open-angle glaucoma (OAG) is the most prevalent type of glaucoma in almost all countries. Primary OAG is a progressive optic neuropathy that causes retinal ganglion cell axon loss and visual field deterioration. Usually, glaucoma progresses gradually over the course of years, and the progression of vision loss can be delayed with treatment [1,2]. A longitudinal cohort study found that the prevalence rate of primary OAG in patients aged $\geq 50$ years was $2.79 \%$ [ 3 ]. In a randomized cohort study, the definite glaucoma prevalence was $1.1 \%$ in patients aged $45-49$ years at the time

Correspondence: Al-Namaeh M, Eye Research Center, LLC, 295 E Swedesford Rd \# 119, Wayne, PA 19087, USA. E-mail: alnamaeh@eyeresearchcenter.org. ORCID iD: https://orcid.org/0000-0002-5253-1175

How to cite this article: Al-Namaeh M. Pharmaceutical treatment of primary open angle glaucoma. Med Hypothesis Discov Innov Optom. 2021 Spring; $2(1): 8-17$. DOI: https://doi.org/10.51329/mehdioptometry120

Received: 22 February 2021 Accepted: 08 April 2021

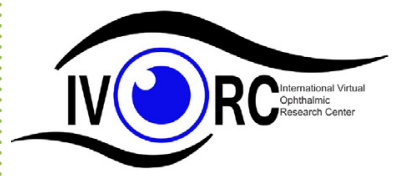

Copyright (C) Author(s). This is an open-access article distributed under the terms of the Creative Commons Attribution-NonCommercial 4.0 International License (http://creativecommons.org/licenses/by-nc/4.0/) which permits copy and redistribute the material just in noncommercial usages, provided the original work is properly cited. (c) (\$) \$ 
of clinical examination [4].

Elevated intraocular pressure (IOP) $[5,6]$ and older age [7-9] are the most important risk factors for the development and progression of primary OAG, of which only IOP is a modifiable factor [10]. Other risk factors include a family history of glaucoma [8,11,12], African American ancestry [13, 14], systemic disease [15], thinner corneas [16], myopia [17], and steroid use [18]. Since IOP is the only modifiable risk factor, management of primary OAG has focused on decreasing IOP, which can delay disease progression, decrease the visual field (VF) loss rate, and protect against visual function loss and vision loss [19].

This review aimed to include current evidence on the primary OAG pharmaceutical treatment. The key concepts of the primary OAG trials performed over the last decade were identified and summarized.

\section{METHODS}

A literature search was conducted using PubMed/MEDLINE and clinicaltrials.gov from January 1, 2010, to August 31, 2020, using the keywords "POAG" and "ocular topical therapeutics." The keyword "completed" was added to the keyword list for the clinicaltrials.gov search. No language limitation was applied. The search of these databases identified 77 and 120 potentially relevant reports, respectively. The full-text review of these papers yielded 33 papers considered to be compatible with our inclusion criteria.

\section{RESULTS}

Table 1 summarizes the characteristics and key findings of the 33 included studies, which were clinical trials and prospective studies. The most frequently used medications for IOP control were prostaglandin (PG) analogues, $\beta$-blockers, carbonic anhydrase inhibitors (CAIs), and $\alpha-2$ adrenergic agonists. PG analogues were the most widely used treatment. Table 2 summarizes the mechanisms of action of each IOP-lowering medication.

PG analogues were prescribed either alone or in combination with $\beta$-blockers, CAIs, and $\alpha-2$ adrenergic agonists. In newly diagnosed, treatment-naive OAG or ocular hypertension (OHT) patients, topical PG analogues, including bimatoprost, latanoprost, and travoprost, were effective at lowering IOP. Although bimatoprost was initially the most effective, no significant difference in efficacy among the different PG analogues was found after 6 months [20]. A prospective, multicenter observational cohort study of 1221 normal, suspected glaucoma, and definite glaucoma subjects revealed the impact of IOP reduction after administration of latanoprost $0.005 \%$ in reducing VF deterioration in newly diagnosed OAG [21]. In another randomized controlled trial (RCT) on newly diagnosed, treatment-naive OAG or OHT patients, patients who did not respond to 1 month of latanoprost were switched to another topical PG (bimatoprost or travoprost) which had no additive benefit [22]. A significant IOP-lowering effect of once-daily travoprost was reported in a clinical trial of patients with OAG or OHT [23]. Once-daily administration of benzalkonium chloride (BAK)-preserved travoprost $0.004 \%$ was an effective IOP-lowering treatment in patients with newly diagnosed primary OAG [24]. Once-daily administration of bimatoprost $0.03 \%$ or travoprost $0.004 \%$ achieved effective IOP reduction in patients with primary OAG or OHT. However, the effect of bimatoprost on the mean IOP was more but not significant [25]. Preservative-free (PF) latanoprost had better tolerability and a comparable IOP-lowering effect as compared to BAK-latanoprost in patients with glaucoma or OHT [26].

In addition to the above trials on PG analogues per se, a few other studies compared their efficacy against different classes of IOP-lowering eye drops. Among adult subjects with unilateral or bilateral OAG or OHT, latanoprostene bunod (LBN) $0.024 \%$ every evening had a greater IOP-lowering effect than timolol $0.5 \%$ twice daily during the daytime, over 3 months of treatment. This study verified the efficacy and safety of LBN [27]. LBN administered at $8 \mathrm{PM}$ had a greater IOP reduction and ocular perfusion pressure increase during the night hours than timolol $0.5 \%$ twice daily in patients with OHT or early primary OAG [28]. The mean 24-hour IOP-lowering effect of bimatoprost $0.01 \%$ and timolol $0.5 \%$ were comparable, but bimatoprost $0.01 \%$ was more effective than timolol $0.5 \%$ during the nocturnal period [29].

The efficacy and safety of either preserved or PF fixed combination (FC) of PG analogues with timolol were also investigated. The efficacy of a PF latanoprost/timolol FC was equivalent to that of BAK-preserved latanoprost/timolol FC. This treatment was well-tolerated in patients with OAG or OHT who were previously treated with the preserved formulation, and the overall safety profile was similar [30]. The IOP-lowering effect of a PF tafluprost $0.0015 \% /$ timolol $0.5 \%$ FC was greater than that of both tafluprost $(0.0015 \%)$ and timolol (0.5\%) monotherapies [31]. The once-daily administration of a FC of latanoprost/timolol further reduced IOP compared with twice daily $0.50 \%$ timolol monotherapy in patients with primary OAG [32]. 
The IOP-lowering effect of a PF tafluprost/timolol FC was comparable to that of a preserved latanoprost/ timolol FC. A tafluprost/timolol FC improved superficial punctate keratopathy scores [33]. Moreover, a PF tafluprost/timolol FC reduced IOP in primary OAG and OHT patients [34]. The IOP-lowering effect of a FC of bimatoprost/timolol in Chinese patients with OAG or OHT was comparable with concurrent dosing with the single components [35]. Once-daily administration of a FC of bimatoprost $0.03 \% /$ timolol maleate $0.5 \%$ had greater IOP-lowering efficacy than the triple combination of dorzolamide $2 \%$, brimonidine $0.2 \%$, and timolol maleate $0.5 \%$, although both treatment types were well-tolerated [36].

An additive IOP-lowering effect of topical brimonidine added to topical PG was seen in patients with primary OAG or OHT, but this effect was less than that of topical timolol as monotherapy [37]. Patients with glaucoma with symptoms or signs of ocular surface disease, who were treated with BAK-preserved latanoprost, were switched to PF tafluprost therapy and a triple PF treatment (tafluprost and dorzolamide/ timolol FC). These patients had significantly lower mean, peak, and fluctuation of 24-hour IOP following treatment with PF-tafluprost, and enhanced ocular surface parameters and tolerability. On the other hand, the triple PF treatment yielded a more significant 24-hour IOP control than latanoprost baseline therapy [38].

The IOP-lowering outcome of PF timolol $0.1 \%$ gel in treatment-naive patients with primary OAG or OHT was effective. Furthermore, this treatment reduced ocular signs and symptoms in patients who were intolerant to preserved eye drops [39]. The IOP-lowering effect of both PF and preserved brimonidine tartrate in patients with OAG or OHT was comparable. Formulations of brimonidine tartrate showed no significant differences in pain, stinging, and blurred vision after instillation. However, at the first instillation, the PF formulation produced a significantly greater burning sensation than the preserved formulation [40].

No significant differences were found in IOP, retrobulbar blood flow velocities, and ocular perfusion pressure between brimonidine/timolol and dorzolamide/timolol FCs after 1 month of treatment in patients with primary OAG [41]. A topical FC of brinzolamide $1 \%$ and brimonidine $0.2 \%$ was safe and effective in lowering IOP in a 3-month period in patients with OHT or OAG, and reduced IOP significantly more than either brinzolamide $1 \%$ or brimonidine $0.2 \%$ monotherapy [42]. Azarga (a FC of brinzolamide $1 \% /$ timolol $0.5 \%$ suspension) had better tolerability than Cosopt (a FC of dorzolamide $2 \% /$ timolol $0.5 \%$ solution) in patients with primary OAG [43]. Administration of topical CAIs either as monotherapy or in combination with other IOP-lowering medications resulted in a significantly greater difference in IOP measured by dynamic contour tonometry (DCT) and Goldmann applanation tonometry (GAT). The diagnosis type (OAG or OHT) and the number of IOP-lowering medications had no significant influence on the difference in IOP as measured using the two instruments [13]. Dorzolamide/timolol and brinzolamide/timolol FCs effectively decreased IOP, which was a lower target IOP with dorzolamide/timolol than with brinzolamide/timolol, in patients with primary OAG or normal tension glaucoma [44].

Rho-kinase inhibitors, such as netarsudil $0.02 \%$ (which has been used since 2018), AR-13324 0.02\%, and ripasudil were recently shown to have IOP-lowering effects. Netarsudil $0.02 \%$ once-daily was non-inferior to timolol. A clinically and statistically significant IOP-lowering effect of netarsudil $0.02 \%$ once-daily has been reported [45]. AR-13324 0.02\% (a small molecule inhibitor of Rho-kinase) was not as efficient as latanoprost in patients with OAG or OHT, with unmedicated IOPs of 22-35 $\mathrm{mmHg}$ [46]. Ripasudil reduced IOP for at least $7 \mathrm{~h}$ following instillation in patients with primary OAG or OHT [47]. Topical administration of ripasudil $0.4 \%$ alone or in combination with PG analogues or $\beta$-blockers over 1 year had sustained IOP-lowering effects and acceptable safety profiles in patients with OAG (primary OAG and exfoliation glaucoma) or OHT [48]. A once-daily FC of netarsudil/latanoprost had a significant IOP-lowering effect, which was superior to that of netarsudil and latanoprost monotherapy, in patients with OAG or OHT [49]. Once-daily netarsudil had a comparable IOP-lowering effect as compared to twice-daily timolol, with similar frequencies of adverse effects and a similar tolerability profile in adults with bilateral OAG or OHT [50]. Finally, MGV354 0.1\% (soluble guanylate cyclase) showed no statistically significant IOP-lowering effect as compared to vehicletreated patients in subjects with OHT or glaucoma [51].

\section{DISCUSSION}

The pathophysiology of primary OAG pertaining to retinal ganglion cell loss is linked to the IOP level. The IOP is dependent on the equilibrium between the aqueous humor of the ciliary body and its drainage by two individual pathways: the trabecular meshwork (conventional) and the uveoscleral (non-conventional) outflow pathways. Primary OAG patients have increased resistance to aqueous outflow through the trabecular meshwork [62]. 
Table 1. Characteristics of included studies in this review and summary of their main concepts

\begin{tabular}{|c|c|c|}
\hline First author & Study design & Main Findings \\
\hline $\begin{array}{l}\text { Faridi et al., } 2010 \\
{[20]}\end{array}$ & $\begin{array}{l}\text { Prospective single-masked } \\
\text { comparative RCT }\end{array}$ & $\begin{array}{l}\text { Bimatoprost, latanoprost, and travoprost had effective IOP-lowering outcomes, but bimatoprost was the } \\
\text { most effective in the initial phase. However, after } 6 \text { months of treatment, the difference in the efficacy of } \\
\text { the three topical PG analogues was not statistically significant. }\end{array}$ \\
\hline $\begin{array}{l}\text { Ge et al., } 2010 \\
{[23]}\end{array}$ & $\begin{array}{l}\text { Open-label, non-comparative } \\
\text { clinical trial }\end{array}$ & A significant IOP-lowering effect of once-daily travoprost in patients with OAG or OHT was found. \\
\hline $\begin{array}{l}\text { Macky et al., } 2010 \\
{[25]}\end{array}$ & $\begin{array}{l}\text { Hospital-based, prospective } \\
\text { RCT }\end{array}$ & $\begin{array}{l}\text { Once-daily administration of bimatoprost } 0.03 \% \text { or travoprost } 0.004 \% \text { achieved effective IOP reduction } \\
\text { in patients with primary OAG or OHT. However, bimatoprost provided a greater, although non-signifi- } \\
\text { cant mean IOP-lowering effect as compared to baseline. }\end{array}$ \\
\hline $\begin{array}{l}\text { Pacella et al., } 2010 \\
{[32]}\end{array}$ & Prospective study & $\begin{array}{l}\text { Once-daily administration of a FC of latanoprost/timolol could further reduce IOP than twice daily } \\
0.50 \% \text { timolol, in patients with primary OAG. }\end{array}$ \\
\hline $\begin{array}{l}\text { Araie et al., } 2012 \\
{[37]}\end{array}$ & Phase III clinical trial & $\begin{array}{l}\text { An additive IOP-lowering effect of topical brimonidine in addition to topical PG in patients with primary } \\
\text { OAG or OHT was found; this treatment was less effective than topical timolol as monotherapy. }\end{array}$ \\
\hline $\begin{array}{l}\text { Nebbioso et al., } \\
2012[43]\end{array}$ & $\begin{array}{l}\text { Prospective, single-masked } \\
\text { study }\end{array}$ & $\begin{array}{l}\text { Better tolerability of Azarga (a FC of brinzolamide } 1 \% / \text { timolol } 0.5 \% \text { suspension) than Cosopt (a FC of } \\
\text { dorzolamide } 2 \% / \text { timolol } 0.5 \% \text { solution) was seen in patients with primary OAG. }\end{array}$ \\
\hline $\begin{array}{l}\text { Siesky et al., } 2012 \\
{[41]}\end{array}$ & $\begin{array}{l}\text { Prospective, randomized, } \\
\text { double-blind, crossover study }\end{array}$ & $\begin{array}{l}\text { The differences in IOP, retrobulbar blood flow velocities, and ocular perfusion pressure between brimo- } \\
\text { nidine/timolol and dorzolamide/timolol were not significant after 1-month treatment in patients with } \\
\text { primary OAG. }\end{array}$ \\
\hline $\begin{array}{l}\text { Katz et al., } 2013 \\
{[42]}\end{array}$ & $\begin{array}{l}\text { Phase III, double-masked, } \\
\text { parallel-group, multicenter } \\
\text { RCT }\end{array}$ & $\begin{array}{l}\text { Topical administration of a FC of brinzolamide } 1 \% / \text { brimonidine } 0.2 \% \text { was safe and effective in IOP } \\
\text { reduction over } 3 \text { months in patients with OHT or OAG, with a significant greater IOP-reduction than } \\
\text { with brinzolamide } 1 \% \text { or brimonidine } 0.2 \% \text { monotherapy. }\end{array}$ \\
\hline $\begin{array}{l}\text { Lascaratos et al., } \\
2013[21]\end{array}$ & $\begin{array}{l}\text { Randomized, dou- } \\
\text { ble-masked, placebo-con- } \\
\text { trolled, multicenter } \\
\text { treatment trial }\end{array}$ & $\begin{array}{l}\text { IOP-lowering with latanoprost } 0.005 \% \text { reduced visual field deterioration of newly diagnosed OAG. The } \\
\text { early stage of the glaucoma and relatively low baseline IOP indicated markedly sensitive case findings in } \\
\text { patients with previously untreated OAG. }\end{array}$ \\
\hline $\begin{array}{l}\text { Tomic et al., } 2013 \\
{[24]}\end{array}$ & Prospective study & $\begin{array}{l}\text { Once-daily administration of BAK-preserved travoprost } 0.004 \% \text { was an effective IOP-lowering treatment } \\
\text { in patients with newly diagnosed primary OAG. }\end{array}$ \\
\hline $\begin{array}{l}\text { Tzamalis et al., } \\
2013[13]\end{array}$ & $\begin{array}{l}\text { A randomized cross-sectional } \\
\text { study }\end{array}$ & $\begin{array}{l}\text { Significant greater difference in IOP measured by DCT and GAT was detected after treatment with } \\
\text { topical CAIs, either as monotherapy or in combination with other IOP-lowering medications. Patient } \\
\text { diagnosis (OAG or OHT) and the number of IOP-lowering medications had no significant influence on } \\
\text { this difference. }\end{array}$ \\
\hline $\begin{array}{l}\text { Bacharach et al., } \\
2014[46]\end{array}$ & $\begin{array}{l}\text { Double-masked, dose-re- } \\
\text { sponse RCT }\end{array}$ & $\begin{array}{l}\text { AR-13324 } 0.02 \% \text { (a small molecule inhibitor of Rho-kinase) had a less marked IOP-lowering effect than } \\
\text { latanoprost in patients with OAG or OHT, with unmedicated IOPs of } 22-35 \mathrm{mmHg} \text {. }\end{array}$ \\
\hline $\begin{array}{l}\text { Garcia-Lopez et } \\
\text { al., } 2014[36]\end{array}$ & $\begin{array}{l}\text { Phase IV, 6-month, investi- } \\
\text { gator-masked, prospective, } \\
\text { crossover multicenter RCT }\end{array}$ & $\begin{array}{l}\text { Once-daily bimatoprost/timolol could have a greater IOP-lowering efficacy than the triple FC of dorzol- } \\
\text { amide } 2 \% \text {, brimonidine } 0.2 \% \text {, and timolol maleate } 0.5 \% \text { (dorz/brim/tim; Krytantek). Both treatment } \\
\text { types were well-tolerated. }\end{array}$ \\
\hline $\begin{array}{l}\text { Ling et al., } 2014 \\
{[35]}\end{array}$ & $\begin{array}{l}\text { Multicenter, double-masked, } \\
\text { parallel controlled RCT }\end{array}$ & $\begin{array}{l}\text { The IOP-lowering effect of a FC of bimatoprost } 0.03 \% / \text { timolol maleate } 0.5 \% \text { was seen in Chinese } \\
\text { patients with OAG or OHT and was comparable with concurrent dosing with the single components. }\end{array}$ \\
\hline $\begin{array}{l}\text { Pfeiffer et al., } 2014 \\
{[31]}\end{array}$ & $\begin{array}{l}\text { Phase III, stratified, } \\
\text { double-masked, multicenter } \\
\text { RCT }\end{array}$ & $\begin{array}{l}\text { The IOP-lowering effect of a PF tafluprost } 0.0015 \% / \text { timolol } 0.5 \% \mathrm{FC} \text { was better than that of tafluprost } \\
0.0015 \% \text { or timolol } 0.5 \% \text { monotherapy. }\end{array}$ \\
\hline $\begin{array}{l}\text { Tanihara et al., } \\
2015[47]\end{array}$ & $\begin{array}{l}\text { Prospective, open-label, } \\
\text { three-period, Latin-square } \\
\text { crossover multicenter RCT }\end{array}$ & Ripasudil reduced IOP within 7 hours after instillation in patients with primary OAG or OHT. \\
\hline $\begin{array}{l}\text { Oddone et al., } \\
2015[29]\end{array}$ & $\begin{array}{l}\text { Prospective, double-masked, } \\
\text { crossover RCT }\end{array}$ & $\begin{array}{l}\text { The mean } 24 \text {-hour IOP-lowering effect of bimatoprost } 0.01 \% \text { and timolol } 0.5 \% \text { are comparable, but } \\
\text { bimatoprost } 0.01 \% \text { was more effective than timolol } 0.5 \% \text { during the night hours. }\end{array}$ \\
\hline $\begin{array}{l}\text { Galose et al., } 2016 \\
{[44]}\end{array}$ & Prospective, controlled, RCT & $\begin{array}{l}\text { Dorzolamide/timolol and brinzolamide/timolol provided effective IOP reduction. The reduction was } \\
\text { greater and lower target pressures were achieved with dorzolamide/timolol than with brinzolamide/ } \\
\text { timolol in patients with primary OAG or normal tension glaucoma. }\end{array}$ \\
\hline $\begin{array}{l}\text { Liu et al., } 2016 \\
{[28]}\end{array}$ & $\begin{array}{l}\text { Prospective, open-label } \\
\text { crossover RCT }\end{array}$ & $\begin{array}{l}\text { LBN eye drop instillation at } 8 \text { PM yielded a greater IOP reduction and ocular perfusion pressure increase } \\
\text { than timolol } 0.5 \% \text { twice daily during the night hours in patients with OHT or early primary OAG. }\end{array}$ \\
\hline $\begin{array}{l}\text { Tanihara et al., } \\
2016[48]\end{array}$ & $\begin{array}{l}\text { Prospective, open-label } \\
\text { clinical trial }\end{array}$ & $\begin{array}{l}\text { Topical administration of ripasudil } 0.4 \% \text { alone or paired with PG analogues or } \beta \text {-blockers over } 1 \text { year had } \\
\text { a sustained IOP-lowering effect and an acceptable safety profile in patients with OAG (primary OAG } \\
\text { and exfoliation glaucoma) or OHT. }\end{array}$ \\
\hline $\begin{array}{l}\text { Weinreb et al., } \\
2016[27]\end{array}$ & $\begin{array}{l}\text { Phase III, double-masked, } \\
\text { parallel-group multicenter } \\
\text { RCT }\end{array}$ & $\begin{array}{l}\text { LBN eye drop instillation every evening yielded a greater IOP-lowering effect than timolol } 0.5 \% \text { twice } \\
\text { daily, in the daytime, in adults with OAG or OHT over a 3-month period of treatment. Efficacy and } \\
\text { safety of LBN was also reported. }\end{array}$ \\
\hline $\begin{array}{l}\text { Konstas et al., } \\
2017[38]\end{array}$ & $\begin{array}{l}\text { Prospective, observ- } \\
\text { er-masked, crossover, } \\
\text { comparison, RCT }\end{array}$ & $\begin{array}{l}\text { Patients with glaucoma and concurrent symptoms or signs of ocular surface disease on BAK-preserved } \\
\text { latanoprost were switched to PF tafluprost therapy or a triple PF regimen (tafluprost and dorzolamide/ } \\
\text { timolol FC). A significantly lower mean, peak, and fluctuation of } 24 \text {-hour IOP was seen after treatment } \\
\text { with PF-tafluprost, along with enhancement of ocular surface parameters and tolerability. The triple PF } \\
\text { medication produced a significantly greater } 24 \text {-hour IOP control than seen with the latanoprost baseline } \\
\text { treatment. }\end{array}$ \\
\hline
\end{tabular}




\begin{tabular}{|c|c|c|}
\hline $\begin{array}{l}\text { Lazreg et al., } 2018 \\
\text { [39] }\end{array}$ & $\begin{array}{l}\text { Phase IV, open-label, } \\
\text { non-controlled, multicenter } \\
\text { RCT }\end{array}$ & $\begin{array}{l}\text { PF timolol } 0.1 \% \text { gel was effective in lowering IOP in treatment-naive patients with primary OAG or } \\
\text { OHT. Furthermore, it reduced ocular signs and symptoms in patients who were intolerant to preserved } \\
\text { eye drops. }\end{array}$ \\
\hline $\begin{array}{l}\text { Serle et al., } 2018 \\
{[45]}\end{array}$ & $\begin{array}{l}\text { Two large double-masked, } \\
\text { noninferiority RCTs }\end{array}$ & $\begin{array}{l}\text { Once-daily netarsudil } 0.02 \% \text { was non-inferior to timolol. A clinically and statistically significant IOP-low- } \\
\text { ering effect of once-daily netarsudil } 0.02 \% \text { was reported. }\end{array}$ \\
\hline $\begin{array}{l}\text { Stacy et al., } 2018 \\
{[51]}\end{array}$ & $\begin{array}{l}\text { Phase I and II, dou- } \\
\text { ble-masked, randomized, and } \\
\text { vehicle-controlled, study }\end{array}$ & $\begin{array}{l}\text { MGV354 0.1\% (soluble guanylate cyclase) had no significant IOP-lowering effect as compared to vehicle } \\
\text { in patients with OHT or glaucoma. }\end{array}$ \\
\hline $\begin{array}{l}\text { Suzuki et al., } 2019 \\
\text { [33] }\end{array}$ & Prospective, open-label RCT & $\begin{array}{l}\text { The IOP-lowering effect of a preserved tafluprost/timolol FC was comparable with that of a preserved } \\
\text { latanoprost/timolol FC. Tafluprost/timolol revealed an improvement in superficial punctate keratopathy } \\
\text { scores. }\end{array}$ \\
\hline $\begin{array}{l}\text { Aptel et al., } 2019 \\
{[30]}\end{array}$ & $\begin{array}{l}\text { Phase II, parallel-group, } \\
\text { investigator-masked RCT }\end{array}$ & $\begin{array}{l}\text { A PF latanoprost/timolol FC showed equivalent efficacy as compared with a BAK-preserved latano- } \\
\text { prost/timolol FC. It was well-tolerated in patients with OAG or OHT who were previously treated with } \\
\text { the preserved formulation, and the overall safety profile was similar. }\end{array}$ \\
\hline $\begin{array}{l}\text { Blondeau et al., } \\
2019[22]\end{array}$ & $\begin{array}{l}\text { A prospective randomized } \\
\text { switch design study }\end{array}$ & $\begin{array}{l}\text { Switching latanoprost to another topical PG (bimatoprost or travoprost) had no additive benefit for } \\
\text { patients who were non-responders to the initiall-month latanoprost treatment. }\end{array}$ \\
\hline $\begin{array}{l}\text { Misiuk-Hojlo et } \\
\text { al., } 2019[26]\end{array}$ & $\begin{array}{l}\text { Prospective, longitudinal, } \\
\text { open-label, multicenter trial }\end{array}$ & $\begin{array}{l}\text { PF latanoprost had better tolerability and a comparable IOP-lowering effect as compared to BAK-latano- } \\
\text { prost in patients with glaucoma or OHT. }\end{array}$ \\
\hline $\begin{array}{l}\text { Asrani et al., } 2020 \\
{[49]}\end{array}$ & $\begin{array}{l}\text { Pooled data of two phase III, } \\
\text { double-masked, multicenter, } \\
\text { active controlled, paral- } \\
\text { lel-group RCTs }\end{array}$ & $\begin{array}{l}\text { A once-daily FC of netarsudil/latanoprost had a significant IOP-lowering effect, which was superior to } \\
\text { netarsudil and latanoprost monotherapy in patients with OAG or OHT. }\end{array}$ \\
\hline $\begin{array}{l}\text { Duru et al., } 2020 \\
{[40]}\end{array}$ & RCT & $\begin{array}{l}\text { The IOP-lowering effect of both PF and preserved brimonidine in patients with OAG or OHT was } \\
\text { comparable. }\end{array}$ \\
\hline $\begin{array}{l}\text { Karlova et al., } \\
2020[34]\end{array}$ & $\begin{array}{l}\text { Prospective multicenter } \\
\text { European RCT }\end{array}$ & A PF tafluprost/timolol FC reduced IOP in primary OAG and OHT. \\
\hline $\begin{array}{l}\text { Singh et al., } 2020 \\
{[50]}\end{array}$ & $\begin{array}{l}\text { Pooled data of the ROCK- } \\
\text { ET- } 1 \text { to }-4 \text { randomized, phase } \\
\text { III trials }\end{array}$ & $\begin{array}{l}\text { Once-daily netarsudil had a comparable IOP-lowering effect against twice-daily timolol, with similar } \\
\text { frequencies of adverse effects and a similar tolerability profile in adults with bilateral OAG or OHT. }\end{array}$ \\
\hline
\end{tabular}

Abbreviations: BAK, benzalkonium chloride; CAIs, Carbonic Anhydrase Inhibitors; DCT, dynamic contour tonometry; FC, fixed combination; GAT, Goldmann applanation tonometry; IOP, Intraocular pressure; LBN, latanoprostene bunod ophthalmic solution 0.024; mmHg, millimeters of mercury; OAG, open angle glaucoma; OHT, ocular hypertension; PG, prostaglandins; PM, afternoon; PF, preservativefree; ROCKET-1, Rho Kinase Elevated IOP Treatment Trial 1; RCT, Randomized Controlled Trial.

Table 2. Summary of mechanism of action of intraocular pressure (IOP)-lowering medications

\begin{tabular}{|c|c|}
\hline Drug Class & Mechanism of action \\
\hline $\begin{array}{l}\text { ROCK inhibitor* and norepineph- } \\
\text { rine transporter inhibitor }\end{array}$ & $\begin{array}{l}\text { The netarsudil IOP-lowering effect was accomplished via three effects on aqueous humor dynam- } \\
\text { ics, including a trabecular-outflow facility increase, and aqueous humor production decrease, as } \\
\text { well as an episcleral venous pressure decrease }[52,53] \text {. }\end{array}$ \\
\hline PG analogues & $\begin{array}{l}\text { Increases uveoscleral outflow. One plausible mechanism may involve induction of metallopro- } \\
\text { teinases in the ciliary body, and breakdown of the extracellular matrix, with subsequent reduction } \\
\text { in outflow resistance through the uveoscleral pathway (traditional PG analogues: bimatoprost, } \\
\text { latanoprost, and travoprost) }[28,54-57] \text {. }\end{array}$ \\
\hline Beta-adrenergic agonists & $\begin{array}{l}\text { Aqueous humor production is apparently activated by a } \beta \text { receptor-mediated cyclic adenosine } \\
\text { monophosphate (AMP) / protein kinase A (PKA) pathway. } \beta \text { blockers blunt adrenergic activa- } \\
\text { tion of this pathway. An additional hypothesis is that ocular blood flow is reduced by } \beta \text { blockers, } \\
\text { which subsequently leads to reduction in the ultrafiltration that controls aqueous production }[58 \text {, } \\
59] \text {. }\end{array}$ \\
\hline Alpha-adrenergic agonists & $\begin{array}{l}\text { Reduce IOP by reducing aqueous humor production, and by enhancing both conventional and } \\
\text { uveoscleral outflow }[60] \text {. }\end{array}$ \\
\hline Carbonic anhydrase Inhibitors & Reduce bicarbonate ion formation and fluid transport, and consequently, the IOP [30]. \\
\hline
\end{tabular}

Currently, IOP is the single modifiable risk factor in the management of glaucoma. The goal of therapy is to prevent or delay glaucoma progression by reducing IOP, regardless of the initial IOP level [9,63]. Pharmaceutical treatment is a common intervention in primary OAG for IOP reduction. The first line of therapy for primary OAG in published guidelines is topical eye drops $[64,65]$. Therefore, we concentrated only on pharmaceutical treatment rather than surgical procedures or laser intervention. 


\section{PG analogues}

PG analogues are more widely used to reduce IOP than other classes [1, 64, 65]. Compared to placebo, bimatoprost, latanoprost, and travoprost are among the most efficacious drugs for decreasing IOP in 3 months, although the variations within the class were small and probably not clinically significant [19]. PG analogues have increasingly replaced $\beta$-adrenergic receptor antagonists as first-line medical therapy because of their oncedaily dosing, low occurrence of systemic side effects, and potent IOP-lowering effect. While PG analogues are the most commonly recommended first-line medications, both PG analogues and $\beta$-blockers are considered as first-line medications to lower IOP $[1,64,65]$. Examples of PG analogues (PGF2 $\alpha$ analogues) available as eye drops are latanoprost, travoprost, bimatoprost, tafluprost, and unoprostone. Unoprostone and tafluprost are available for prescription in Japan. Generic latanoprost has been demonstrated to be no less, and probably more effective than its branded counterparts, in avoiding the need for additional treatment modalities [66]. Patients who were non-responsive to latanoprost did not benefit from switching to other topical PG analogues [22].

$\mathrm{PF}$ latanoprost has at least the same IOP-reducing effectiveness as BAK-preserved latanoprost, with a higher tolerability profile. This could result in better treatment control and improved quality of life [26]. Once-daily administration of travoprost reduced IOP [23]. BAK-preserved travoprost $0.004 \%$ disrupted the tear film stability in the long-term, despite having a significant IOP-lowering effect [24]. Bimatoprost, latanoprost, and travoprost were effective at lowering IOP, with comparable long-term results [20].

\section{Beta-adrenergic antagonists}

Nonselective $\beta$-blockers that bind to both $\beta 1$ and $\beta 2$ receptors include timolol, levobunolol, metipranolol, and carteolol [58]. The $\beta 1$-selective antagonist betaxolol is available for ophthalmic use, but is less effective. PF timolol $0.1 \%$ gel effectively reduced IOP in treatment-naive patients [39].

\section{Alpha-adrenergic agonists}

If the use of PG analogues or $\beta$-receptor antagonists is contraindicated, other agents, such as $\alpha-2$ adrenergic receptor agonists or topical CAIs, can be administered as first-line treatment. Examples of $\alpha$-adrenergic agonists are brimonidine tartrate ophthalmic solution $0.1 \%$ or $0.15 \%$ (Alphagan-P), brimonidine tartrate ophthalmic solution $0.2 \%$, and apraclonidine HCL $0.5 \%$ or $1 \%$ (Idopidine). PF brimonidine tartrate and preserved brimonidine $\% 0.15$ preparations decreased IOP at a similar rate [40].

\section{Carbonic anhydrase inhibitors}

Examples of CAIs are dorzolamide and brinzolamide. A FC of PF latanoprost/timolol T2347 showed similar efficacy to that of BAK-preserved latanoprost/timolol [30]. In comparison, a triple PF tafluprost with PF dorzolamide/timolol FC resulted in a significant improvement in 24-hour IOP control as compared to the latanoprost baseline treatment [38]. Administration of CAIs either as monotherapy or in combination with other IOP-lowering medications resulted in a statistically significant difference in IOP measured by DCT and GAT [13].

\section{Rho-kinase inhibitors}

Treatment with netarsudil $0.02 \%$ ophthalmic solution (a Rho-kinase inhibitor) was effective and well-tolerated once-daily in patients with OHT and OAG $[45,50]$. The administration of $0.4 \%$ ripasudil, another Rho-kinase inhibitor, for 52 weeks resulted in a decrease in IOP and an acceptable safety profile in patients with OAG or OHT, whether treated as monotherapy or additive therapy [48].

\section{Fixed combination products}

All four classes of pharmaceuticals can be applied as additive second- or third-line treatments. The $\beta$-receptor antagonist timolol has been paired with CAIs, such as dorzolamide in a single medication. In addition, timolol was combined with the $\alpha-2$ adrenergic agonist brimonidine. Furthermore, a brinzolamide/brimonidine combination has recently been introduced, and a latanoprost/timolol combination is also widely available. These combinations minimize the number of drops required and enhance patient compliance. A once-daily FC of netarsudil/latanoprost had a significant IOP-lowering effect, which was superior to that of netarsudil and latanoprost monotherapy in patients with OAG or OHT [49]. The PF tafluprost/timolol FC decreased IOP when administered in combination, as compared to as monotherapy [31,33, 35]. In addition, another study showed that PF tafluprost/timolol yielded the greatest decrease in IOP at week 4 , and that this was sustained throughout the 6-month study duration [34]. The IOP-lowering effect of bimatoprost and timolol was comparable 
at 24 hours [29]. Once-daily bimatoprost/timolol may have better IOP-lowering efficacy than dorzolamide/ bimatoprost/timolol [36]. Topical brimonidine has an additive IOP-lowering effect when added to topical PG analogues, but its IOP-lowering effect was lower than that of topical timolol monotherapy [37]. Brinzolamide $1 \%$ plus timolol $0.5 \%$ suspension is more tolerable than dorzolamide $2 \%$ plus timolol $0.5 \%$ [ 43 ]. A once-daily latanoprost/timolol combination reduced IOP and retained IOP control over the 24-month observation period [32].

LBN $0.024 \%$ demonstrated greater IOP-lowering effects than timolol $0.5 \%$ twice daily, during daytime, over 3 months of treatment [28]. LBN (administered at 8 PM) induced more IOP reduction and increased ocular perfusion pressure during the nocturnal period more than timolol (administered at $8 \mathrm{AM}$ and $8 \mathrm{PM}$ ) [28]. After 1 month of treatment, brimonidine/timolol and dorzolamide/timolol resulted in well-controlled IOP in OAG patients, with a significant difference in the IOP [41]. The IOP-lowering effect of MGV354 0.1\%, which is a soluble guanylate cyclase, was not significant [51].

In primary OAG patients, an FC of brinzolamide $1 \%$ /brimonidine $0.2 \%$ was a safe and effective IOPlowering therapy and provided a significantly greater IOP-lowering activity as compared to either brinzolamide or brimonidine monotherapy [42]. Both FCs of brinzolamide/timolol and of dorzolamide/timolol provided effective IOP reduction, although patients treated with dorzolamide/timolol were more likely to achieve lower target pressures than those treated with brinzolamide/timolol [44]. Both bimatoprost and travoprost effectively decreased IOP, but bimatoprost provided a larger, although statistically non-significant, reduction in mean IOP from baseline [25]. In treatment-naive patients with IOPs of $22-35 \mathrm{mmHg}$, netarsudil (AR-13324) $0.02 \%$, was not as effective as latanoprost [46].

There is a very strong correlation between the baseline, untreated IOP level and the amount of IOP reduction, and there appears to be a lower threshold of about $15 \mathrm{mmHg}$ where treatment did not yield any IOP reduction. The importance of the disclosure of the baseline IOP level in addition to the IOP-lowering effect of drugs has been acknowledged [63].

A strength of this review is that it focused on primary OAG pharmaceutical interventions. In addition, the mechanism of action of each drug class was summarized, and new interventions, such as netarsudil and ripasudil, which are inhibitors of Rho-kinase, were discussed. Additionally, it provided an update on the latest FC interventions that have been studied in clinical trials. The limitation of this review is that it did not include a discussion of any laser or surgical procedures. Future studies focusing on both the safety and efficacy of available drug classes, besides the effects of their FC eye drops on compliance and adherence of patients with glaucoma, could provide a more comprehensive and practical overview of the outcomes of pharmaceutical treatment of glaucoma.

\section{CONCLUSIONS}

This review highlighted that new medications yield a significant decrease in IOP in patients with primary OAG. Primary OAG is a cause of irreversible vision loss. If it is not diagnosed and treated early, the condition is likely to progress in many patients, and the long-term risk of blindness is considerable. This review highlights that the novel Rho-kinase inhibitors have shown significant IOP reduction and that new FCs markedly reduce IOP.

\section{ETHICAL DECLARATIONS}

Ethical approval: This study was a review and no ethical approval was required. Conflict of interests: None.

\section{FUNDING}

None.

\section{ACIKNOWLED GMENT}

\section{None.}

\section{REFERENCES}

1. Boland MV, Ervin AM, Friedman DS, Jampel HD, Hawkins BS, Vollenweider D, et al. Comparative effectiveness of treatments for open-angle glaucoma: a systematic review for the U.S. Preventive Services Task Force. Ann Intern Med. 2013;158(4):271-9. doi: 10.7326/0003-4819-158-4-201302190-00008 pmid: 23420235 
2. Friedman DS, Wolfs RC, O'Colmain BJ, Klein BE, Taylor HR, West S, et al. Prevalence of open-angle glaucoma among adults in the United States. Arch Ophthalmol. 2004;122(4):532-8. doi: 10.1001/archopht.122.4.532 pmid: 15078671

3. Kreft D, Doblhammer G, Guthoff RF, Frech S. Prevalence, incidence, and risk factors of primary open-angle glaucoma - a cohort study based on longitudinal data from a German public health insurance. BMC Public Health. 2019;19(1):851. doi: 10.1186/s12889-0196935-6 pmid: 31262269

4. Karvonen E, Stoor K, Luodonpaa M, Hagg P, Kuoppala J, Lintonen T, et al. Prevalence of glaucoma in the Northern Finland Birth Cohort Eye Study. Acta Ophthalmol. 2019;97(2):200-7. doi: 10.1111/aos.13912 pmid: 30198084

5. Ocular Hypertension Treatment Study G, European Glaucoma Prevention Study G, Gordon MO, Torri V, Miglior S, Beiser JA, et al. Validated prediction model for the development of primary open-angle glaucoma in individuals with ocular hypertension. Ophthalmology. 2007;114(1):10-9. doi: 10.1016/j.ophtha.2006.08.031 pmid: 17095090

6. McMonnies CW. The significance of intraocular pressure elevation during sleep-related postures. Clin Exp Optom. 2014;97(3):221-4. doi: $10.1111 /$ cxo. 12108 pmid: 24024831

7. Suzuki Y, Iwase A, Araie M, Yamamoto T, Abe H, Shirato S, et al. Risk factors for open-angle glaucoma in a Japanese population: the Tajimi Study. Ophthalmology. 2006;113(9):1613-7. doi: 10.1016/j.ophtha.2006.03.059 pmid: 16828504

8. Le A, Mukesh BN, McCarty CA, Taylor HR. Risk factors associated with the incidence of open-angle glaucoma: the visual impairment project. Invest Ophthalmol Vis Sci. 2003;44(9):3783-9. doi: 10.1167/iovs.03-0077 pmid: 12939292

9. Miglior S, Zeyen T, Pfeiffer N, Cunha-Vaz J, Torri V, Adamsons I, et al. Results of the European Glaucoma Prevention Study. Ophthalmology. 2005;112(3):366-75. doi: 10.1016/j.ophtha.2004.11.030 pmid: 15745761

10. Bengtsson B, Heijl A, Johannesson G, Andersson-Geimer S, Aspberg J, Linden C. The Glaucoma Intensive Treatment Study (GITS), a randomized clinical trial: design, methodology and baseline data. Acta Ophthalmol. 2018;96(6):557-66. doi: 10.1111/aos.13791 pmid: 30171664

11. Nemesure B, He Q, Mendell N, Wu SY, Hejtmancik JF, Hennis A, et al. Inheritance of open-angle glaucoma in the Barbados family study. Am J Med Genet. 2001;103(1):36-43. doi: 10.1002/ajmg.1498 pmid: 11562932

12. Wu J, Hewitt AW, Green CM, Ring MA, McCartney PJ, Craig JE, et al. Disease severity of familial glaucoma compared with sporadic glaucoma. Arch Ophthalmol. 2006;124(7):950-4. doi: 10.1001/archopht.124.7.950 pmid: 16832017

13. Tzamalis A, Kynigopoulos M, Chalvatzis N, Dimitrakos S, Schlote T. Association of ocular hypotensive medication types with dynamic contour tonometry and Goldmann applanation tonometry measurements in a glaucoma and ocular hypertensive population.J Ocul Pharmacol Ther. 2013;29(1):41-7. doi: 10.1089/jop.2012.0115 pmid: 23066787

14. Sample PA, Girkin CA, Zangwill LM, Jain S, Racette L, Becerra LM, et al. The African Descent and Glaucoma Evaluation Study (ADAGES): design and baseline data. Arch Ophthalmol. 2009;127(9):1136-45. doi: 10.1001/archophthalmol.2009.187 pmid: 19752422

15. Song X, Mitnitski A, Rockwood K. Prevalence and 10-year outcomes of frailty in older adults in relation to deficit accumulation. J Am Geriatr Soc. 2010;58(4):681-7. doi: 10.1111/j.1532-5415.2010.02764.x pmid: 20345864

16. Beutelspacher SC, Serbecic N, Scheuerle AF. Assessment of central corneal thickness using OCT, ultrasound, optical low coherence reflectometry and Scheimpflug pachymetry. Eur J Ophthalmol. 2011;21(2):132-7. doi: 10.5301/ejo.2010.1093 pmid: 20872361

17. Miki A, Ikuno Y, Asai T, Usui S, Nishida K. Defects of the Lamina Cribrosa in High Myopia and Glaucoma. PLoS One. 2015;10(9):e0137909. doi: 10.1371/journal.pone.0137909 pmid: 26366870

18. Jones R, 3rd, Rhee DJ. Corticosteroid-induced ocular hypertension and glaucoma: a brief review and update of the literature. Curr Opin Ophthalmol. 2006;17(2):163-7. doi: 10.1097/01.icu.0000193079.55240.18 pmid: 16552251

19. Li T, Lindsley K, Rouse B, Hong H, Shi Q, Friedman DS, et al. Comparative Effectiveness of First-Line Medications for Primary Open-Angle Glaucoma: A Systematic Review and Network Meta-analysis. Ophthalmology. 2016;123(1):129-40. doi: 10.1016/j. ophtha.2015.09.005 pmid: 26526633

20. Faridi UA, Saleh TA, Ewings P, Venkateswaran M, Cadman DH, Samarasinghe RA, et al. Comparative study of three prostaglandin analogues in the treatment of newly diagnosed cases of ocular hypertension, open-angle and normal tension glaucoma. Clin Exp Ophthalmol. 2010;38(7):678-82. doi: 10.1111/j.1442-9071.2010.02305.x pmid: 20456437

21. Lascaratos G, Garway-Heath DF, Burton R, Bunce C, Xing W, Crabb DP, et al. The United Kingdom Glaucoma Treatment Study: a multicenter, randomized, double-masked, placebo-controlled trial: baseline characteristics. Ophthalmology. 2013;120(12):2540-5 doi: 10.1016/j.ophtha.2013.07.054 pmid: 24126032

22. Blondeau P, Hamid M, Ghalie Z. Prospective randomized clinical trial on the effects of latanoprost, travoprost and bimatoprost on latanoprost non-responders. J Fr Ophtalmol. 2019;42(8):894-9. doi: 10.1016/j.jfo.2019.02.009 pmid: 31164290

23. Ge J, Sun XH, Wang NL, Zhao JL, Wu LL, Chen XM, et al. Intraocular pressure lowering efficacy and safety of travoprost $0.004 \%$ as a replacement therapy in patients with open angle glaucoma or ocular hypertension. Chin Med J (Engl). 2010;123(11):1417-21. pmid: 20819599

24. Tomic M, Kastelan S, Soldo KM, Salopek-Rabatic J. Influence of BAK-preserved prostaglandin analog treatment on the ocular surface health in patients with newly diagnosed primary open-angle glaucoma. Biomed Res Int. 2013;2013:603782. doi: 10.1155/2013/603782 pmid: 23971041

25. Macky TA. Bimatoprost versus travoprost in an Egyptian population: a hospital-based prospective, randomized study. J Ocul Pharmacol Ther. 2010;26(6):605-10. doi: 10.1089/jop.2010.0068 pmid: 21034177

26. Misiuk-Hojlo M, Pomorska M, Mulak M, Rekas M, Wierzbowska J, Prost M, et al. The RELIEF study: Tolerability and efficacy of preservative-free latanoprost in the treatment of glaucoma or ocular hypertension. Eur J Ophthalmol. 2019;29(2):210-5. doi: $10.1177 / 1120672118785280$ pmid: 29998767

27. Weinreb RN, Scassellati Sforzolini B, Vittitow J, Liebmann J. Latanoprostene Bunod 0.024\% versus Timolol Maleate 0.5\% in Subjects with Open-Angle Glaucoma or Ocular Hypertension: The APOLLO Study. Ophthalmology. 2016;123(5):965-73. doi: 10.1016/j. ophtha.2016.01.019 pmid: 26875002

28. Liu JHK, Slight JR, Vittitow JL, Scassellati Sforzolini B, Weinreb RN. Efficacy of Latanoprostene Bunod 0.024\% Compared With Timolol 0.5\% in Lowering Intraocular Pressure Over 24 Hours. Am J Ophthalmol. 2016;169:249-57. doi: 10.1016/j.ajo.2016.04.019 pmid: 27457257

29. Oddone F, Rossetti L, Tanga L, Berardo F, Ferrazza M, Michelessi M, et al. Effects of Topical Bimatoprost $0.01 \%$ and Timolol $0.5 \%$ on Circadian IOP, Blood Pressure and Perfusion Pressure in Patients with Glaucoma or Ocular Hypertension: A Randomized, Double Masked, Placebo-Controlled Clinical Trial. PLoS One. 2015;10(10):e0140601. doi: 10.1371/journal.pone.0140601 pmid: 26484767

30. Aptel F, Pfeiffer N, Schmickler S, Clarke J, Lavin-Dapena C, Moreno-Montanes J, et al. Noninferiority of Preservative-free Versus BAK-preserved Latanoprost-timolol Fixed Combination Eye Drops in Patients With Open-angle Glaucoma or Ocular Hypertension. J Glaucoma. 2019;28(6):498-506. doi: 10.1097/IJG.0000000000001248 pmid: 31166287

31. Pfeiffer N, Traverso CE, Lorenz K, Saarela V, Liinamaa J, Uusitalo H, et al. A 6-month study comparing efficacy, safety, and tolerability of the preservative-free fixed combination of tafluprost $0.0015 \%$ and timolol $0.5 \%$ versus each of its individual preservative-free compo- 
nents. Adv Ther. 2014;31(12):1228-46. doi: 10.1007/s12325-014-0163-3 pmid: 25447269

32. Pacella E, Pacella F, Cavallotti C, Librando A, Feher J, Pecori-Giraldi J. The combination latanoprost-timolol versus twice daily $0.50 \%$ timolol administration either associated or not with latanoprost: efficacy and tolerability in the primary open-angle glaucoma. Eur Rev Med Pharmacol Sci. 2010;14(5):477-80. pmid: 20556928

33. Suzuki K, Otsuka N, Hizaki H, Hashimoto M, Kuwayama Y, Tafluprost/Timolol Versus Latanoprost/Timolol Study G. Correction to: Multicenter, Randomized, Controlled Study Comparing Tafluprost/Timolol Fixed Combination with Latanoprost/Timolol Fixed Combination in Primary Open-Angle Glaucoma and Ocular Hypertension. Adv Ther. 2019;36(2):492-4. doi: 10.1007/s12325-0180864-0 pmid: 30617814

34. Karlova EV, Petrov SY, Germanova VN. [Preservative-free fixed combination in the treatment of open-angle glaucoma and ocular hypertension: the VISIONARY Study (EUPAS22204)]. Vestn Oftalmol. 2020;136(4):76-84. doi: 10.17116/oftalma202013604176 pmid: 32779459

35. Ling Z, Zhang M, Hu Y, Yin Z, Xing Y, Fang A, et al. Safety and efficacy of bimatoprost/timolol fixed combination in Chinese patients with open-angle glaucoma or ocular hypertension. Chin Med J (Engl). 2014;127(5):905-10. pmid: 24571886

36. Garcia-Lopez A, Paczka JA, Jimenez-Roman J, Hartleben C. Efficacy and tolerability of fixed-combination bimatoprost/timolol versus fixed-combination dorzolamide/brimonidine/timolol in patients with primary open-angle glaucoma or ocular hypertension: a multicenter, prospective, crossover study. BMC Ophthalmol. 2014;14:161. doi: 10.1186/1471-2415-14-161 pmid: 25527295

37. Araie M, Yamazaki Y, Sugiyama K, Kuwayama Y, Tanihara H. [Phase III clinical trial of brimonidine in patients with primary open-angle glaucoma and ocular hypertension--comparison of the effects of brimonidine monotherapy versus timolol monotherapy, or combination brimonidine/prostaglandins therapy versus combination placebo/prostaglandins therapy]. Nippon Ganka Gakkai Zasshi. 2012;116(10):955-66. pmid: 23285843

38. Konstas AG, Boboridis KG, Kapis P, Marinopoulos K, Voudouragkaki IC, Panayiotou D, et al. 24-Hour Efficacy and Ocular Surface Health with Preservative-Free Tafluprost Alone and in Conjunction with Preservative-Free Dorzolamide/Timolol Fixed Combination in Open-Angle Glaucoma Patients Insufficiently Controlled with Preserved Latanoprost Monotherapy. Adv Ther. 2017;34(1):221-35. doi: 10.1007/s12325-016-0448-9 pmid: 27913991

39. Lazreg S, Merad Z, Nouri MT, Garout R, Derdour A, Ghroud N, et al. Efficacy and safety of preservative-free timolol $0.1 \%$ gel in open-angle glaucoma and ocular hypertension in treatment-naive patients and patients intolerant to other hypotensive medications. J Fr Ophtalmol. 2018;41(10):945-54. doi: 10.1016/j.jfo.2018.04.012 pmid: 30477719

40. Duru Z, Ozsaygili C. Preservative-free versus preserved brimonidine $\% 0.15$ preparations in the treatment of glaucoma and ocular hypertension: short term evaluation of efficacy, safety, and potential advantages. Cutan Ocul Toxicol. 2020;39(1):21-4. doi: 10.1080/15569527.2019.1680685 pmid: 31615279

41. Siesky B, Harris A, Ehrlich R, Cantor L, Shoja MM, Rusia D, et al. Short-term effects of brimonidine/timolol and dorzolamide/timolol on ocular perfusion pressure and blood flow in glaucoma. Adv Ther. 2012;29(1):53-63. doi: 10.1007/s12325-011-0092-3 pmid: 22246943

42. Katz G, Dubiner H, Samples J, Vold S, Sall K. Three-month randomized trial of fixed-combination brinzolamide, $1 \%$, and brimonidine, 0.2\%. JAMA Ophthalmol. 2013;131(6):724-30. doi: 10.1001/jamaophthalmol.2013.188 pmid: 23579344

43. Nebbioso M, Evangelista M, Librando A, Di Blasio D, Pescosolido N. Fixed topical combinations in glaucomatous patients and ocular discomfort. Expert Opin Pharmacother. 2012;13(13):1829-35. doi: 10.1517/14656566.2012.705830 pmid: 22770575

44. Galose MS, Elsaied HM, Macky TA, Fouad PH. Brinzolamide/timolol versus dorzolamide/timolol fixed combinations: A hospital-based, prospective, randomized study. Indian J Ophthalmol. 2016;64(2):127-31. doi: 10.4103/0301-4738.179718 pmid: 27050347

45. Serle JB, Katz LJ, McLaurin E, Heah T, Ramirez-Davis N, Usner DW, et al. Two Phase 3 Clinical Trials Comparing the Safety and Efficacy of Netarsudil to Timolol in Patients With Elevated Intraocular Pressure: Rho Kinase Elevated IOP Treatment Trial 1 and 2 (ROCKET-1 and ROCKET-2). Am J Ophthalmol. 2018;186:116-27. doi: 10.1016/j.ajo.2017.11.019 pmid: 29199013

46. Bacharach J, Dubiner HB, Levy B, Kopczynski CC, Novack GD, Group A-CS. Double-masked, randomized, dose-response study of AR-13324 versus latanoprost in patients with elevated intraocular pressure. Ophthalmology. 2015;122(2):302-7. doi: 10.1016/j. ophtha.2014.08.022 pmid: 25270273

47. Tanihara H, Inoue T, Yamamoto T, Kuwayama Y, Abe H, Suganami H, et al. Intra-ocular pressure-lowering effects of a Rho kinase inhibitor, ripasudil (K-115), over 24 hours in primary open-angle glaucoma and ocular hypertension: a randomized, open-label, crossover study. Acta Ophthalmol. 2015;93(4):e254-60. doi: 10.1111/aos.12599 pmid: 25487877

48. Tanihara H, Inoue T, Yamamoto T, Kuwayama Y, Abe H, Fukushima A, et al. One-year clinical evaluation of $0.4 \%$ ripasudil (K-115) in patients with open-angle glaucoma and ocular hypertension. Acta Ophthalmol. 2016;94(1):e26-34. doi: 10.1111/aos.12829 pmid: 26338317

49. Asrani S, Bacharach J, Holland E, McKee H, Sheng H, Lewis RA, et al. Fixed-Dose Combination of Netarsudil and Latanoprost in Ocular Hypertension and Open-Angle Glaucoma: Pooled Efficacy/Safety Analysis of Phase 3 MERCURY-1 and -2. Adv Ther. 2020;37(4):1620-31. doi: 10.1007/s12325-020-01277-2 pmid: 32166538

50. Singh IP, Fechtner RD, Myers JS, Kim T, Usner DW, McKee H, et al. Pooled Efficacy and Safety Profile of Netarsudil Ophthalmic Solution 0.02\% in Patients With Open-angle Glaucoma or Ocular Hypertension. J Glaucoma. 2020;29(10):878-84. doi: 10.1097/ IJG.0000000000001634 pmid: 32826769

51. Stacy R, Huttner K, Watts J, Peace J, Wirta D, Walters T, et al. A Randomized, Controlled Phase I/II Study to Evaluate the Safety and Efficacy of MGV354 for Ocular Hypertension or Glaucoma. Am J Ophthalmol. 2018;192:113-23. doi: 10.1016/j.ajo.2018.05.015 pmid: 29802818

52. Wang RF, Williamson JE, Kopczynski C, Serle JB. Effect of 0.04\% AR-13324, a ROCK, and norepinephrine transporter inhibitor, on aqueous humor dynamics in normotensive monkey eyes. J Glaucoma. 2015;24(1):51-4. doi: 10.1097/IJG.0b013e3182952213 pmid: 25535688

53. Kiel JW, Kopczynski CC. Effect of AR-13324 on episcleral venous pressure in Dutch belted rabbits. J Ocul Pharmacol Ther. 2015;31(3):146-51. doi: 10.1089/jop.2014.0146 pmid: 25756366

54. Lim KS, Nau CB, O’Byrne MM, Hodge DO, Toris CB, McLaren JW, et al. Mechanism of action of bimatoprost, latanoprost, and travoprost in healthy subjects. A crossover study. Ophthalmology. 2008;115(5):790-5 e4. doi: 10.1016/j.ophtha.2007.07.002 pmid: 18452763

55. Addis VM, Miller-Ellis E. Latanoprostene bunod ophthalmic solution $0.024 \%$ in the treatment of open-angle glaucoma: design, development, and place in therapy. Clin Ophthalmol. 2018;12:2649-57. doi: 10.2147/OPTH.S156038 pmid: 30587912

56. Lu LJ, Tsai JC, Liu J. Novel Pharmacologic Candidates for Treatment of Primary Open-Angle Glaucoma. Yale J Biol Med. 2017;90(1):111-8. pmid: 28356898

57. Cavet ME, DeCory HH. The Role of Nitric Oxide in the Intraocular Pressure Lowering Efficacy of Latanoprostene Bunod: Review of Nonclinical Studies. J Ocul Pharmacol Ther. 2018;34(1-2):52-60. doi: 10.1089/jop.2016.0188 pmid: 28783422 
58. Frishman WH, Fuksbrumer MS, Tannenbaum M. Topical ophthalmic beta-adrenergic blockade for the treatment of glaucoma and ocular hypertension. J Clin Pharmacol. 1994;34(8):795-803. doi: 10.1002/j.1552-4604.1994.tb02042.x pmid: 7962666

59. Negri L, Ferreras A, Iester M. Timolol $0.1 \%$ in Glaucomatous Patients: Efficacy, Tolerance, and Quality of Life. J Ophthalmol. 2019;2019:4146124. doi: 10.1155/2019/4146124 pmid: 31191995

60. Apatachioae I, Chiselita D. [Alpha-2 adrenergic agonists in the treatment of glaucoma]. Oftalmologia. 1999;47(2):35-40. pmid: 10641099

61. Sturdivant JM, Royalty SM, Lin CW, Moore LA, Yingling JD, Laethem CL, et al. Discovery of the ROCK inhibitor netarsudil for the treatment of open-angle glaucoma. Bioorg Med Chem Lett. 2016;26(10):2475-80. doi: 10.1016/j.bmcl.2016.03.104 pmid: 27072905

62. Weinreb RN, Aung T, Medeiros FA. The pathophysiology and treatment of glaucoma: a review. JAMA. 2014;311(18):1901-11. doi 10.1001/jama.2014.3192 pmid: 24825645

63. Heijl A, Leske MC, Hyman L, Yang Z, Bengtsson B, Group E. Intraocular pressure reduction with a fixed treatment protocol in the Early Manifest Glaucoma Trial. Acta Ophthalmol. 2011;89(8):749-54. doi: 10.1111/j.1755-3768.2009.01852.x pmid: 20236252

64. Prum BE Jr, Rosenberg LF, Gedde SJ, Mansberger SL, Stein JD, Moroi SE, et al. Primary Open-Angle Glaucoma Preferred Practice Pattern $\left(^{\circledR}\right)$ Guidelines. Ophthalmology. 2016 Jan;123(1):P41-P111. doi: 10.1016/j.ophtha.2015.10.053. Epub 2015 Nov 12. Erratum in: Ophthalmology. 2018 Jun; 125(6):949 pmid: 26581556

65. National Collaborating Centre for Acute Care (UK). Glaucoma: Diagnosis and Management of Chronic Open Angle Glaucoma and Ocular Hypertension. London: National Collaborating Centre for Acute Care (UK); 2009 Apr. pmid: 21938863

66. Kim DH, Addis VM, Pan W, VanderBeek BL. Comparative Effectiveness of Generic Latanoprost Versus Branded Prostaglandin Analogs for Primary Open Angle Glaucoma. Ophthalmic Epidemiol. 2019;26(1):63-71. doi: 10.1080/09286586.2018.1516786 pmid: 30188773 